\title{
Serious Game Development for Color and Object Name Recognition in Early Childhood Education
}

\author{
Ferdian Aditya Pratama ${ }^{1}$, Riana Magdalena ${ }^{2}$, Stafani Prima Dias $^{3}$, \\ Davin Jeremiah Alamsyah ${ }^{4}$ \\ Atma Jaya Catholic University of Indonesia \\ 1ferdian.aditya@atmajaya.ac.id, ${ }^{2}$ riana.magdalena@atmajaya.ac.id, \\ ${ }^{3}$ stefani.primadyas@atmajaya.ac.id, ${ }^{4}$ davin.201804560003@student.atmajaya.ac.id
}

\begin{abstract}
The concept of playing and learning in the classroom has begun to change from playing using physical toys to playing using a computer such as games. The use of serious games as a learning media can help the improvement of dopamine hormones in human body, which is responsible for bringing pleasure and joy to our mind. When that hormone is triggered, the children will be easier to understand the information provided through the game. TKK Mitra has several problems, such as (1) The old computer with a low spec that they had, so it would be difficult for them to download or to install the new game. (2) The lack of games that can be used for teaching the children, so they often get bored quickly. This research use the Iterative methodology consists of requirement, analysis and design, implementation, testing, and evaluation. The purpose of this research is to design an educational PC game. The result of this research is an education game for color and object recognition in English for early childhood education.
\end{abstract}

Keyword- Early Childhood Education, Game Design, Education Game, Serious Game.

\section{INTRODUCTION}

Early Childhood Education is the stage where children will receive a series of lessons and knowledge that will contribute to their whole learning process [1]. Because the childhood period is where they can specifically receptive to the stimuli given to him [2]. Learning with playing is one of the most important in early childhood education
[3]. The implementation of learning and playing concepts can develop the children's experiences in learning, improving their imagination, and affect their learning behavior [4]. The use of information technology in early childhood education nowadays is also become the central element in their learning process [5]. It is also affecting the way children play from physical toys to digital games. Digital game nowadays is become a part of human lifestyle, and just like social media game also has an aspect like audio and visual too [6]. Many teachers also considering the use of digital games as a learning process in the class [7]. Not only the students but at the same time, the use of the game as a learning media also challenge the educator to be creative too [8].

Serious game is one of the learning media that can be used to build an interactive learning atmosphere in the class because it implements the concept of "learning by doing" [9]. The researcher has shown how open-ended serious game can facilitate students' development of specific skills and improve learning performance through problem-solving [10]. They can help expressing and translating existing narratives, social conflicts, and institutional response in a game context [11]. The teacher can also use serious games as the development of competency media [12]. In designing an educational game, we must consider not only the visual aspect but also the problem-solving aspect too [13].

The use of serious games as a learning media can help improving human hormones called dopamine, which is responsible for the pleasure and joy in our mind. When people feel happy, they are most likely to archive a 
lot of more positive things such as learn better, improve the problem-solving ability, broaden the focus, and attention to the subjects [14]. Besides, the using of serious games can also help the student to improve their cognitive skill [15].

TKK Mitra is one of the kinder garden school in BSD. They also implement the concept of learning by playing in every class. But unfortunately, they have some issues in their computer class regarding the (1) old specification of their computer, and it gives them a hard time downloading and installing the new games from the internet. (2) The lack number of serious games that they have, so the children attend to get bored quickly.

Based on that problem, the purpose of this research is to design a serious game as learning media. The introduction of colors and object names in English is the material that taught through this serious game. The learning material in this game is based on the curriculum that TKK Mitra uses in their class. The result of this research is a serious game that TKK Mitra will use in their class.

\section{METHOD}

The serious game development process in this research is using the iterative method as the methodology, and it is as in Figure 1 below.

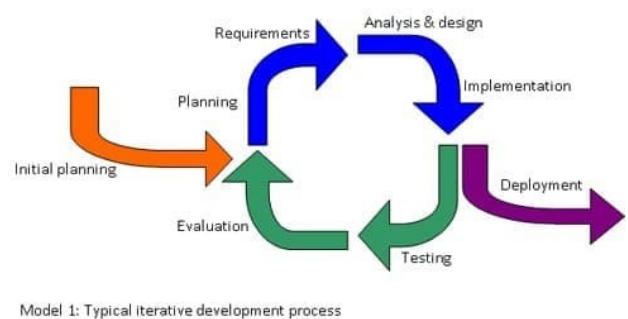

Figure 1. Iterative Method

The methodology itself consists of 5 main steps:

\section{A. Planning and Requirement.}

In this step, the authors are gathering all the user requirements. The purpose of this step is to decide what is the learning material of the games. From this step, the authors and the user choose that the game's content will be a general knowledge like Math and English.

\section{B. Analysis Design}

In this step, the authors begin to design the game concept like how is the story, game control/game flow, game characters, game environment, music and audio, and the game engine itself.

\section{Implementation}

In this step, the authors begin to develop the game based on the design in the previous step. The development process of the game is using Unity as the game engine and $\mathrm{CH}$ as the programming language.

\section{Testing}

In this step, the authors will proceed with the testing process. Black box testing is the method that will use in this step. Black box testing will allow the authors to know about the success or failure of all the functionality in the game. From that, we can also know whether the expected results are the same as the obtained results.

\section{E. Evaluation}

In this step, the authors will evaluate all the game functionality and the learning material with the user. The purpose of this step is to make sure that all requirements are met.

\section{RESULT AND DISCUSSION}

There are a few main components in this game, such as game story, game control/game flow, game character, game environment, and audio.

\section{A. Game Story}

This game raises the story of two animal characters who invite players to be able to play and learn together. Interactions that occur in this game are 2-way, which means players must also be involved to help the characters in the game in completing the game. The storyline used is one-way, which means the player cannot return to the previous stage if he/she has completed the stage. The home page of this game is as in Figure 2. 


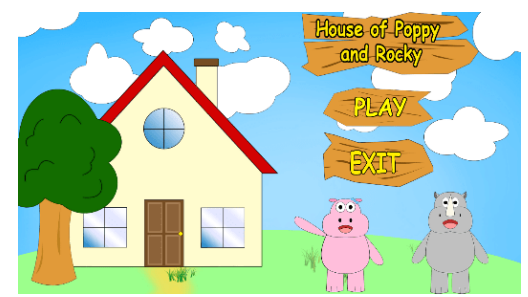

\section{B. Game Control/ Game Flow}

The game was designed for Windows OS only, and it only required the mouse to play the game. The game flow is as in Figure 3.

Figure 2. Main Page of The Game.

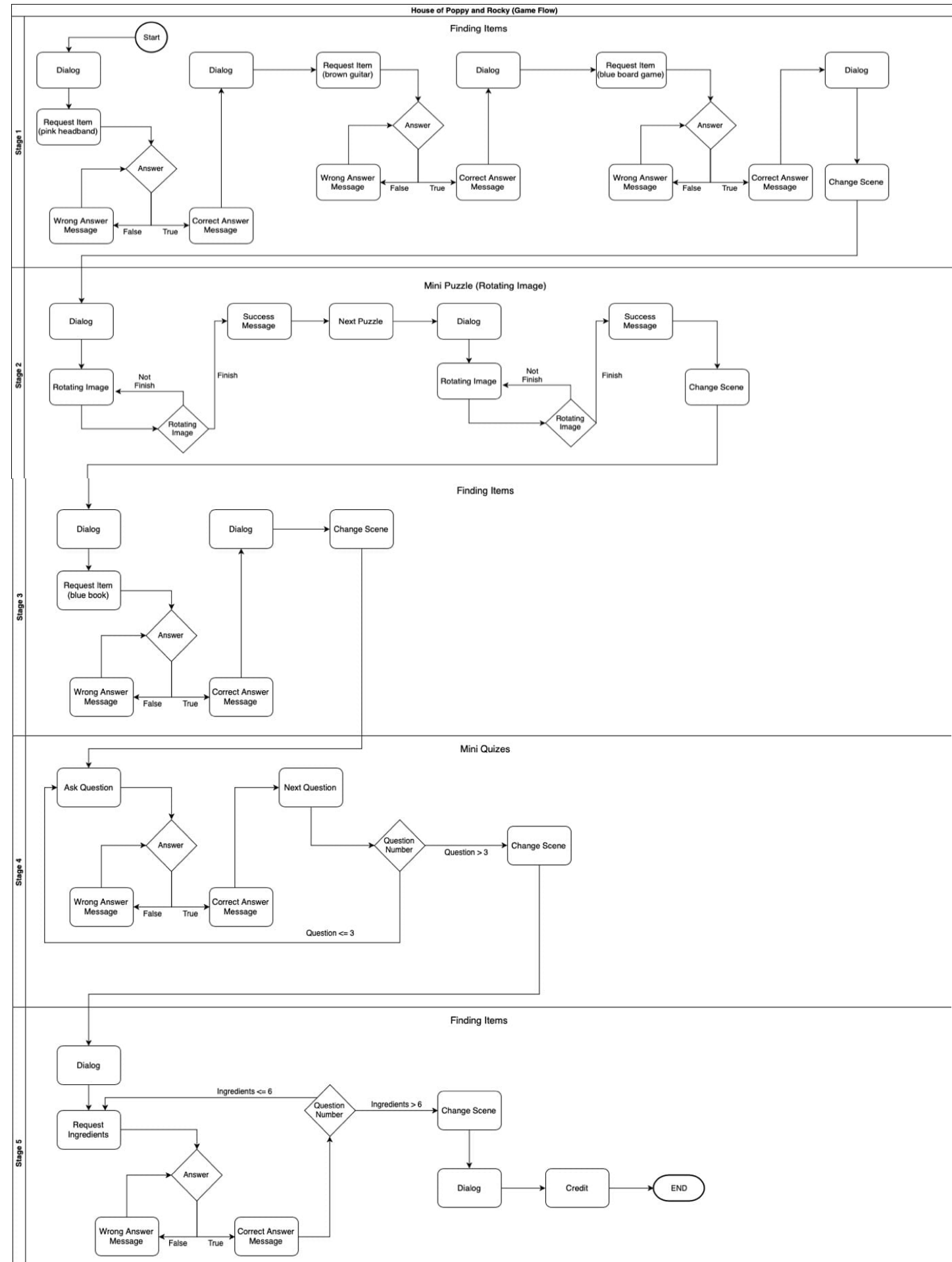

Figure 3. Game Flow 


\section{Game Character}

This game has two main characters, namely Poppy and Rocky. This character is a Non-Player Character (NPC) who will accompany the player for the whole stages to complete this game. The design of the characters used is as in Figure 4.
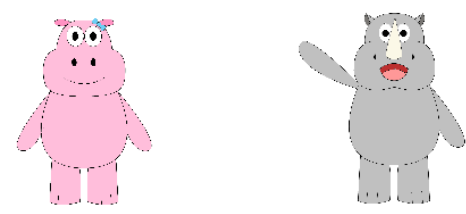

Figure 4. Game Characters.

\section{Game Environment}

This game has five stages in total and it consists of three main stages (1) finding items, (2) mini-puzzle, (3) mini-quizzes, which divided into five stages. The game is using English as the primary language.

\section{Stage One}

The first stage of the game is about finding items. In this stage, the player must find all the items that the NPC asked. The NPC will mention the name of the required object along with the color of the object in English. There are three items that the player must find in this stage to proceed to the next stage, (1) pink headband, (2) brown guitar, and (3) blue boardgame. The first stage interface is as in Figure 5.

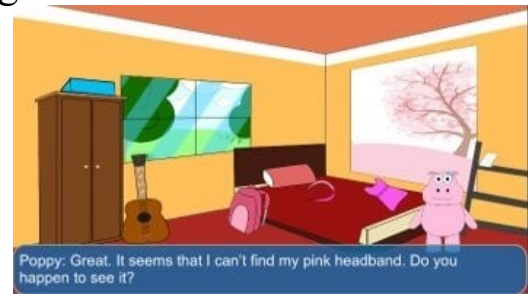

Figure 5. First Stage Interface.

\section{Stage Two}

The second stage of this game is about mini-puzzle. NPC will give the player a simple puzzle of a $3 \times 2$ image. All that player needs to do is rotating the image until all the images are in the correct position. Figure 6 is the second stage interface.

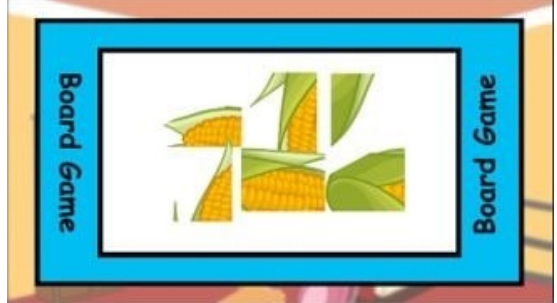

Figure 6. Second Stage Interface

There are two puzzles in total that the player needs to finish in order to go to the next stage. When the player can manage to complete each of mini-puzzle, the NPC will mention what is that object along with the color in English. There are two object names introduced in this stage, (1) yellow corn, and (2) brown puppy. There is no time limit to finish the mini-puzzle.

\section{Stage Three}

Like the first stage, the third stage is about finding items too. But in this stage, the player only needs to find one item only that NPC asked, which is a blue book. Figure 7 is the third stage interface.

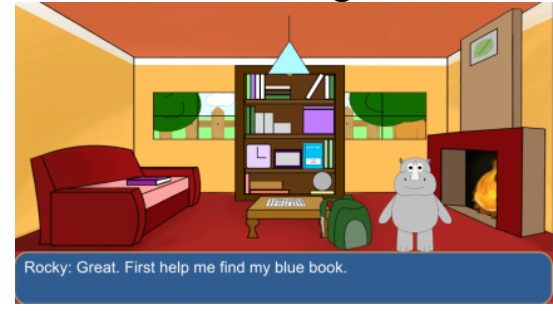

Figure 7. Third Stage Interface.

\section{Stage Four}

The fourth stage is about mini-quizzes. The player is required to answer three multiple answer questions from NPC correctly. The mini-quizzes are consist of (1) simple math, (2) the color of the object, and (3) the object name in English. The fourth stage interface is as in Figure 8.

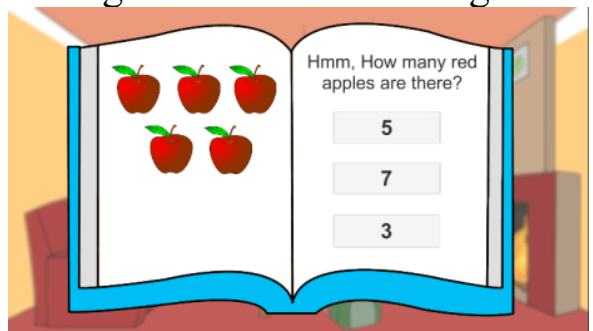

Figure 8. Fourth Stage Interface.

\section{Stage Five}


The fifth stage is about finding items too. In this stage, the player is required to find 6 out of 15 food ingredients. The NPC will mention the name of ingredients along with its color, and the player needs to find those ingredients. The fifth stage interface is as in Figure 9.

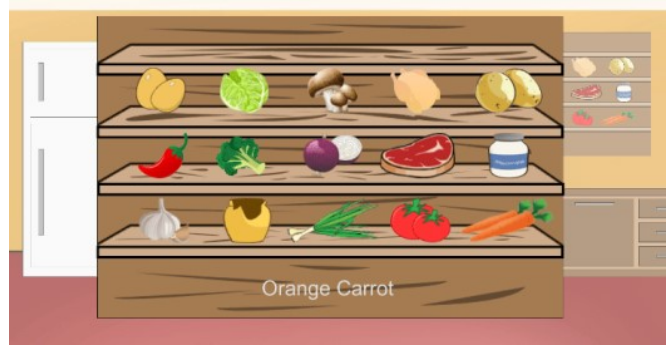

Figure 9. Fifth Stage Interface.

\section{E. Game Audio}

The audio used in this game is for the background music and the dialogue between NPCs with the player and fellow NPCs. All the audio was edited with open source audio software called Audacity. The Audio editing interface is as in Figure 10.

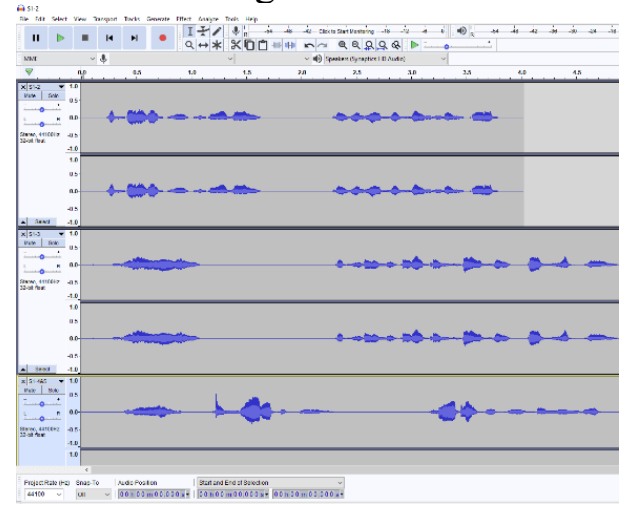

Figure 10. Audio Editing Interface.

\section{TESTING}

Black Box testing was performed to test all the functionality of this game. There are nine main functionalities (1) dialog box, (2) continue button, (3) character audio, (4) object/items selection, (5) rotating image puzzle, (6) answer quiz button, (7) finding items (ingredients), (8) play and exit button, (9) finding items. The result of Black Box testing is as in Table 1.

Table 1. The Result of Black Box Testing

\begin{tabular}{|l|l|l|l|}
\hline Function & $\begin{array}{l}\text { Expected } \\
\text { Result }\end{array}$ & $\begin{array}{l}\text { Result } \\
\text { Obtained }\end{array}$ & Status \\
\hline
\end{tabular}

\begin{tabular}{|c|c|c|c|}
\hline (1) & $\begin{array}{l}\text { Dialog box } \\
\text { appears }\end{array}$ & $\begin{array}{l}\text { Dialog box } \\
\text { appears }\end{array}$ & Valid. \\
\hline (2) & $\begin{array}{l}\text { The text and } \\
\text { audio clip } \\
\text { dialog } \\
\text { changed } \\
\text { sequentially } \\
\text { when the } \\
\text { continue } \\
\text { button } \\
\text { pressed. }\end{array}$ & $\begin{array}{l}\text { The text and } \\
\text { audio clip } \\
\text { dialog } \\
\text { changed } \\
\text { sequentially } \\
\text { when the } \\
\text { continue } \\
\text { button } \\
\text { pressed. }\end{array}$ & Valid. \\
\hline (3) & $\begin{array}{l}\text { The playing } \\
\text { of the audio } \\
\text { clip is } \\
\text { correct in } \\
\text { every stage. }\end{array}$ & $\begin{array}{l}\text { The playing } \\
\text { of the audio } \\
\text { clip is } \\
\text { correct in } \\
\text { every stage. }\end{array}$ & Valid. \\
\hline \multirow[b]{2}{*}{ (4) } & $\begin{array}{l}\text { Play the } \\
\text { correct audio } \\
\text { clip and } \\
\text { show the } \\
\text { dialog text } \\
\text { when the } \\
\text { player } \\
\text { chooses the } \\
\text { right answer. }\end{array}$ & $\begin{array}{l}\text { Play the } \\
\text { correct audio } \\
\text { clip and } \\
\text { show the } \\
\text { dialog text } \\
\text { when the } \\
\text { player } \\
\text { chooses the } \\
\text { right answer. }\end{array}$ & Valid \\
\hline & $\begin{array}{l}\text { Play the } \\
\text { incorrect } \\
\text { audio clip } \\
\text { and show the } \\
\text { dialog text } \\
\text { when the } \\
\text { player } \\
\text { chooses the } \\
\text { wrong } \\
\text { answer. }\end{array}$ & $\begin{array}{l}\text { Play the } \\
\text { incorrect } \\
\text { audio clip } \\
\text { and show the } \\
\text { dialog text } \\
\text { when the } \\
\text { player } \\
\text { chooses the } \\
\text { wrong } \\
\text { answer. }\end{array}$ & Valid. \\
\hline (5) & $\begin{array}{l}\text { Play the } \\
\text { audio clip } \\
\text { when all the } \\
\text { puzzle is in } \\
\text { the correct } \\
\text { position. }\end{array}$ & $\begin{array}{l}\text { Play the } \\
\text { audio clip } \\
\text { when all the } \\
\text { puzzle is in } \\
\text { the correct } \\
\text { position. }\end{array}$ & Valid. \\
\hline \multirow[b]{2}{*}{ (6) } & $\begin{array}{l}\text { Play the } \\
\text { correct audio } \\
\text { clip and } \\
\text { show the } \\
\text { correct sign } \\
\text { if the player } \\
\text { chooses the } \\
\text { right answer. }\end{array}$ & $\begin{array}{l}\text { Play the } \\
\text { correct audio } \\
\text { clip and } \\
\text { show the } \\
\text { correct sign } \\
\text { if the player } \\
\text { chooses the } \\
\text { right answer. }\end{array}$ & Valid. \\
\hline & $\begin{array}{l}\text { Play the } \\
\text { incorrect } \\
\text { audio clip } \\
\text { and show the } \\
\text { incorrect } \\
\text { sign if the } \\
\text { player } \\
\text { chooses the } \\
\text { wrong } \\
\text { answer. }\end{array}$ & $\begin{array}{l}\text { Play the } \\
\text { incorrect } \\
\text { audio clip } \\
\text { and show the } \\
\text { incorrect } \\
\text { sign if the } \\
\text { player } \\
\text { chooses the } \\
\text { wrong } \\
\text { answer. }\end{array}$ & Valid. \\
\hline
\end{tabular}




\begin{tabular}{|c|c|c|c|}
\hline \multirow[b]{2}{*}{ (7) } & $\begin{array}{l}\text { Play the } \\
\text { correct audio } \\
\text { clip and } \\
\text { show the } \\
\text { correct sign } \\
\text { if the player } \\
\text { chooses the } \\
\text { right answer. }\end{array}$ & $\begin{array}{l}\text { Play the } \\
\text { correct audio } \\
\text { clip and } \\
\text { show the } \\
\text { correct sign } \\
\text { if the player } \\
\text { chooses the } \\
\text { right answer. }\end{array}$ & Valid. \\
\hline & $\begin{array}{l}\text { Play the } \\
\text { incorrect } \\
\text { audio clip } \\
\text { and show the } \\
\text { incorrect } \\
\text { sign if the } \\
\text { player } \\
\text { chooses the } \\
\text { wrong } \\
\text { answer. }\end{array}$ & $\begin{array}{l}\text { Play the } \\
\text { incorrect } \\
\text { audio clip } \\
\text { and show the } \\
\text { incorrect } \\
\text { sign if the } \\
\text { player } \\
\text { chooses the } \\
\text { wrong } \\
\text { answer. }\end{array}$ & Valid. \\
\hline \multirow{2}{*}{ (8) } & $\begin{array}{l}\text { Enter stage } \\
\text { one if the } \\
\text { play button } \\
\text { clicked. }\end{array}$ & $\begin{array}{l}\text { Enter stage } \\
\text { one if the } \\
\text { play button } \\
\text { clicked. }\end{array}$ & Valid. \\
\hline & $\begin{array}{l}\text { Exit from the } \\
\text { game if the } \\
\text { exit button } \\
\text { clicked. }\end{array}$ & $\begin{array}{l}\text { Exit from the } \\
\text { game if the } \\
\text { exit button } \\
\text { clicked. }\end{array}$ & Valid \\
\hline \multirow[b]{2}{*}{ (9) } & $\begin{array}{l}\text { Play the } \\
\text { correct audio } \\
\text { clip and } \\
\text { show the } \\
\text { dialog text } \\
\text { when the } \\
\text { player } \\
\text { chooses the } \\
\text { right answer. }\end{array}$ & $\begin{array}{l}\text { Play the } \\
\text { correct audio } \\
\text { clip and } \\
\text { show the } \\
\text { dialog text } \\
\text { when the } \\
\text { player } \\
\text { chooses the } \\
\text { right answer. }\end{array}$ & Valid \\
\hline & $\begin{array}{l}\text { Play the } \\
\text { incorrect } \\
\text { audio clip } \\
\text { and show the } \\
\text { dialog text } \\
\text { when the } \\
\text { player } \\
\text { chooses the } \\
\text { wrong } \\
\text { answer. }\end{array}$ & $\begin{array}{l}\text { Play the } \\
\text { incorrect } \\
\text { audio clip } \\
\text { and show the } \\
\text { dialog text } \\
\text { when the } \\
\text { player } \\
\text { chooses the } \\
\text { wrong } \\
\text { answer. }\end{array}$ & Valid. \\
\hline
\end{tabular}

Based on table 1, all the functionalities are work correctly, and the obtained result from all functionalities are the same as the expected result.

\section{CONCLUSION}

There are some primary elements of the game that we must consider when designing a serious game, (1) game story, (2) game control/ game flow, (3) game character, (4) game environment, (5) game audio. The story of this game is one-way storyline, which means the player cannot return to the previous stage if he/she has completed the stage. The purpose of the story is to invite the players to play and learn together. The game was designed for Windows OS only, and it only required the mouse to play the game. This game has two main characters that will help the players to play and learn, Poppy and Rocky. The characters itself is inspired by rhinos and hippos animal. In general, this game consists of five stages in total and it consists of three main stages, finding items, mini-puzzle, and mini-quizzes. All the audio used in this game was edited with open source audio software called Audacity The development process also not limited only to one tool. The teachers from TKK Mitra can use this game as an interactive learning media for their students. In the next research, the authors will try to analyze the acceptance of the game as a learning media.

\section{REFERENCES}

[1] F. M. M. Lucas, "The game as an early childhood learning resource for intercultural," in 7th International Conference on Intercultural Education "Education, Health and ICT for a Transcultural World", Almeria, 2016.

[2] W. Febriyanto, T. B. Chandrawati and E. Widyarto, "Game Design to Introduce Pets," SISFORMA, vol. 3, no. 1, pp. 33-38, 2016.

[3] S. Hinske, M. Langheinrich and M. Lampe, "Towards guidelines for designing augmented toy environments," Cape Town, 2008.

[4] R. M. Yilmaz, "Educational magic toys developed with augmented reality technology," Computer in Human Behavior, vol. 54, pp. 240 - 248, 2015.

[5] M. Plumb and K. Kautz, "Barriers to the Integration of Information Technology within Early Childhood Education and Care Organisations: A Review of the Literature," Adelaide, 2015.

[6] A. R. Putra, E. Widyarto and A. Dwiyoga, "Wana Warrior Game As 
Animal Rescue Campaign Media," SISFORMA, vol. 4, no. 1, pp. 1-6, 2017.

[7] C.-Y. Hsu, M.-J. Tsai, Y.-H. Chang and J.-C. Liang, "Surveying In-Service Teachers' Beliefs about Game-Based Learning and Perceptions of Technological Pedagogical and Content Knowledge of Games," Educational Technology \& Society, vol. 20, no. 1, pp. 134 - 143, 2016.

[8] E. M. Dukut, C. A. Wulandari and T. B. Chandrawati, "Designing Tommy and Pokina Educative Language Game Software: a Transnational Popular Culture Project," SISFORMA, vol. 5, no. 2, pp. 51-61, 2018.

[9] S. L. Rahayu and Fujiati, "Penerapan Game Design Document dalam Perancangan Game Edukasi yang Interaktif Untuk Menarik Minat," Jurnal Teknologi Informasi dan Ilmu Komputer, vol. 5, no. 3, pp. 341 - 346, 2018.

[10] J. Kang, M. Liu and W. Qu, "Using Gameplay Data To Examine Learning Behavior Patterns In A Serious Game," Computer In Human Behavior, pp. 114, 2016.
[11] K. Gugerell and C. Zuidema, "Gaming For The Energy Transition. Experimenting And Learning In CoDesigning A Serious Game Prototype," Journal of Cleaner Production, pp. 112, 2017.

[12] M. J. Sousa and Á. Rocha, "Leadership styles and skills developed through game-based learning," Journal of Business Research, vol. 94, pp. 360366, 2019.

[13] G. Kalmpourtzis, L. Vrysis and A. Veglis, "Teaching game design to students of the early childhood through Forest Maths," in 11th International Workshop on Semantic and Social Media Adaptation and Personalization (SMAP), 2016.

[14] A. Widhiyasa, Gamification to the rescue, Jakarta: Agate Level Up, 2019.

[15] H. S. Hsiao and J. C. Chen, "Using a Gesture Interactive Game-Based Learning Approach to Improve Preschool Children's Learning Performance and Motor Skill," Computer \& Education, vol. 95, pp. $151-162,2016$. 